\title{
THE INFLUENCE OF KINESIO TAPING ON THE INCREASE OF EFFORT TOLERANCE IN PATIENTS AFTER LAPAROSCOPIC CHOLECYSTECTOMY
}

\author{
Marcin Krajczy ${ }^{1,2}$, Jan Szczegielniak ${ }^{1}$, Katarzyna Bogacz', Jacek Luniewski' \\ Opole University of Technology ${ }^{1}$ \\ Public Hospital in Nysa ${ }^{2}$
}

\begin{abstract}
SUMMARY
Physiotherapy in patients after laparoscopic cholecystectomy $(\mathrm{CHL})$ is impeded by post-operative pain which causes a decline in patients' activity, reduces respiratory muscle function and affects patients' ability to look after themselves.

The aim of this study was to assess the influence of Kinesio Taping (KT) on the increase in effort tolerance in patients after laparoscopic cholecystectomy.

The task of the research was to compare results of 100-meter walk test in test group and control group before surgery, during and after physiotherapy.

The research included 63 patients after CHL treated in General Surgery Department of Hospital in Nysa. Both test group (BA) and control group $(\mathrm{KO})$ included randomly selected volunteers who met test qualification criteria. BA group consisted of 32 patients (26 females and 6 males), KO group consisted of 31 patients (22 females and 9 males). Both groups were subjected to complex physiotherapy and group BA had additional KT applications. The results were subjected to statistical analysis with the use of $U$ MannWhitney test. The level of statistical significance was established at $p<0.05$.

The results showed that in the test conducted before surgery the level of median time recorded in the 100-meter test did not differ significantly between the two research groups. In further tests, the 100-meter walk test time was significantly shorter in the test group in comparison with the patients from the control group.

Conclusion: The improvement in effort tolerance observed in the research indicates the efficiency of Kinesio Taping as a method complementing physiotherapy in patients after laparoscopic cholecystectomy.
\end{abstract}

Keywords: Kinesio Taping, laparoscopic cholecystectomy, physiotherapy.

\section{INTRODUCTION}

Surgeries within abdominal cavity result in body function disorders such as reduction in peristalsis of digestive tract. Post-operative pain and reduced effort tolerance are significant problems occurring after surgeries [1, 2]. Kinesio Taping (KT), which might have beneficial effects on the rehabilitation process, is one of the methods supporting physiotherapy after surgeries. $\mathrm{KT}$ is one of the methods complementing physiotherapy which might have a positive effect on the stabilization of post-operative wound and improve effort tolerance. The theory of the influence KT method suggests that the reduction of the tension in painful structures, by means of preventing them from excessive stretch in detoning applications, decreases pain receptors stimulation [3, 4].
The positive influence of KT has been proved in cases of pregnant women suffering from back pain $[5,6]$.

It seems that the positive effect of KT applications in patients after laparoscopic cholecystectomy $(\mathrm{CHL})$ might also result from early recovery of peristalsis. Reducing the duration of post-operative intestinal atony decreases abdominal oedema, thus weakening scar stretch, and it may stimulate proper diaphragm positioning and lung function.

The aim of the research was to assess the influence of KT applications on the increase in effort tolerance in patients after laparoscopic cholecystectomy.

The research was approved by the Bioethics Committee of Opole Medical Association in the resolution no 150 passed on April, 12th 2007.

\section{RESEARCH METHODS}

The research included 63 patients after $\mathrm{CHL}$ treated in General Surgery Department of Hospital in Nysa between April 2007 and August 2008.

Both test group (BA) and control group (KO) included randomly selected volunteers who met test qualification criteria. Patients qualified for physiotherapy gave informed consent to participate in the research. The BA group consisted of 32 patients ( 26 female and 6 male) who were given standard physiotherapy and KT applications. The KO group comprised 31 patients
(22 female and 9 male) who were given standard physiotherapy only (Table 1).

Criteria for inclusion in the research were as follows:

1. Scheduled CHL surgery.

2. Lack of contraindications for participating in the research program stated by a doctor.

3. Age between 40 and 60 years.

Criteria for exclusion from the research:

1. Absence of patient's consent.

2. Age above 60. 
3. Age below 40 .

4. Cardio-pulmonary insufficiency (NYHA class III and IV, FEV1 value below $40 \%$ of predicted value).

5. Serious general condition due to post-operative complications.

6. Fever.

Table 1. Characteristics of test group (BA) and control group (KO)

\begin{tabular}{|c|c|c|c|c|c|c|c|}
\hline \multicolumn{4}{|c|}{ Group charakteristics } & \multicolumn{3}{c|}{ Patients' age, years } & \\
\hline Group & $\begin{array}{c}\text { No of } \\
\text { patients }\end{array}$ & Females & Males & $\bar{x}$ & $\begin{array}{c}\text { Min } \\
\text { age }\end{array}$ & $\begin{array}{c}\text { Max } \\
\text { age }\end{array}$ & SD \\
\hline BA & 32 & 26 & 6 & 52.21 & 40 & 60 & 5.97 \\
\hline KO & 31 & 22 & 9 & 49.93 & 40 & 60 & 6.55 \\
\hline
\end{tabular}

Criteria for discontinuing participation in the research:

1. Deterioration in patient's condition.

2. Patient's unwillingness to cooperate.

After excluding contraindications, precisely 24 hours after surgery, the following KT applications were used in the BA group:

1. Muscle application - detoning (directed from distal to proximal attachment) applied to external oblique abdominal muscles on the left side.

2. Muscle application - detoning, applied to internal oblique muscles on the right side,

3. Fascial application - applied to liver area (Figure 1).

Before surgery, during and on completing physiotherapy, control 100-meter walk tests were conducted. Before the tests patients had blood pressure and pulse checked in the seated position. Also, subjective tiredness level was determined on the 20-point Borg scale. The physiotherapist clearly explained the rules for conducting the test to the patient. The test was conducted in a specially selected, straight section of the hospital corridor, always at the same time in the morning. The corridor section was 50 meters long with posts marking the end and a colored tape marking the starting line.

The patient walked along the corridor, back and forth, at the highest possible pace to cover the distance of 100 meters. Running was not allowed in the test. The patient was allowed to adjust the pace of walking to the subjective feeling of tiredness. The patient was advised to reduce the speed, stop for rest or even terminate the test if the feeling of tiredness, dyspnea or pain in the abdominal area appeared. After completing the test, the patient was seated in a comfortable, relaxing position for blood pressure and pulse to be checked. In the meantime, the patient filled in the Borg scale of perceived exertion form (6-20 Borg Scale).

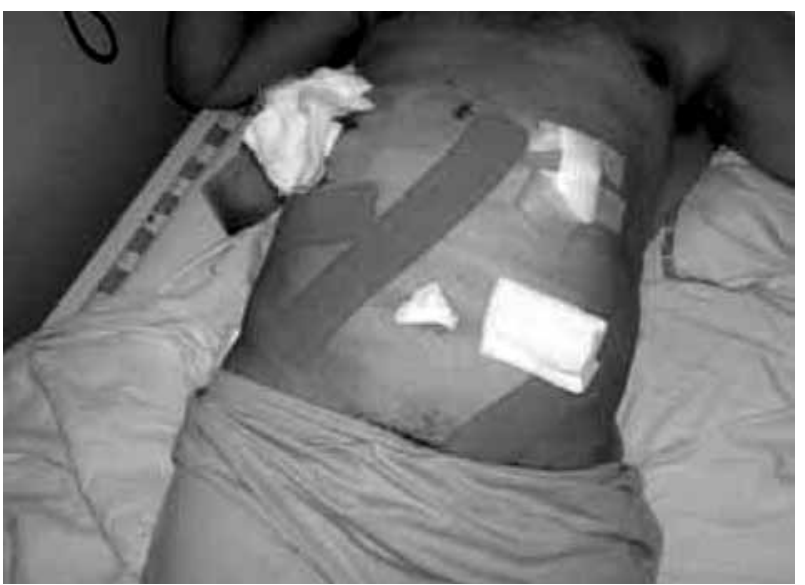

Figure 1. KT application for abdominal muscles and liver fascia

The test was discontinued in the following situations [7]:

- intensifying feeling of tiredness or dyspnea,

- significant increase in the abdominal area pain,

- paleness or turning blue,

- balance disorder,

- chest pain.

The test was conducted, in accordance with test protocol, before the surgery, on the third and on the eighth day after $\mathrm{CHL}$ surgery.

Statistical analysis was conducted with the use of Statistica 7.1 program. The results were presented as arithmetic mean and standard deviation values. Median, quartile and extreme (max. and min.) values were determined as well.

Depending on the level of significance and interactions, contrasting analysis and post hoc analysis were carried out before and after the surgery. Nonparametric rank-sum $U$ Mann-Whitney test was used. For all analyzes, the level of statistical significance was established at $p<0.05$.

\section{RESULTS}

The contrastive analysis of parameters recorded before the surgery shows that the results achieved by patients from BA and $\mathrm{KO}$ groups did not differ significantly.

To assess patients' functional state, 100-meter walk test results recorded before the surgery, on the third and eighth day after surgery were analyzed (Table 2).

The analysis showed that in the test carried out before surgery, the level of average time values did not differ significantly between groups BA and KO. In the consecutive tests average time achieved in the 100-meter walk was significantly shorter in the BA group in comparison with the $\mathrm{KO}$ group.
Table 2. The result of 100-meter walk test and standard deviation (secs) in the tests

\begin{tabular}{|c|c|c|}
\hline Test day & $\begin{array}{c}\text { Test group (BA) } \\
\bar{x} \pm \text { SD }\end{array}$ & $\begin{array}{c}\text { Control group (KO) } \\
\bar{x} \pm \text { SD }\end{array}$ \\
\hline Initial & $60.28 \pm 10.05$ & $59.55 \pm 8.89$ \\
\hline $3^{\text {rd }}$ day & $63.41 \pm 8.91$ & $77.07 \pm 14.04$ \\
\hline $8^{\text {th }}$ day & $56.13 \pm 6.08$ & $68.26 \pm 9.67$ \\
\hline
\end{tabular}

A post hoc analysis showed a significantly longer test time achieved by the patients from the KO group on the third and eighth day after surgery (Figure 2). The 
final test showed significantly shorter time recorded for patients from the BA group in comparison with the initial test time. Average time values were significantly higher for patients from the KO group.

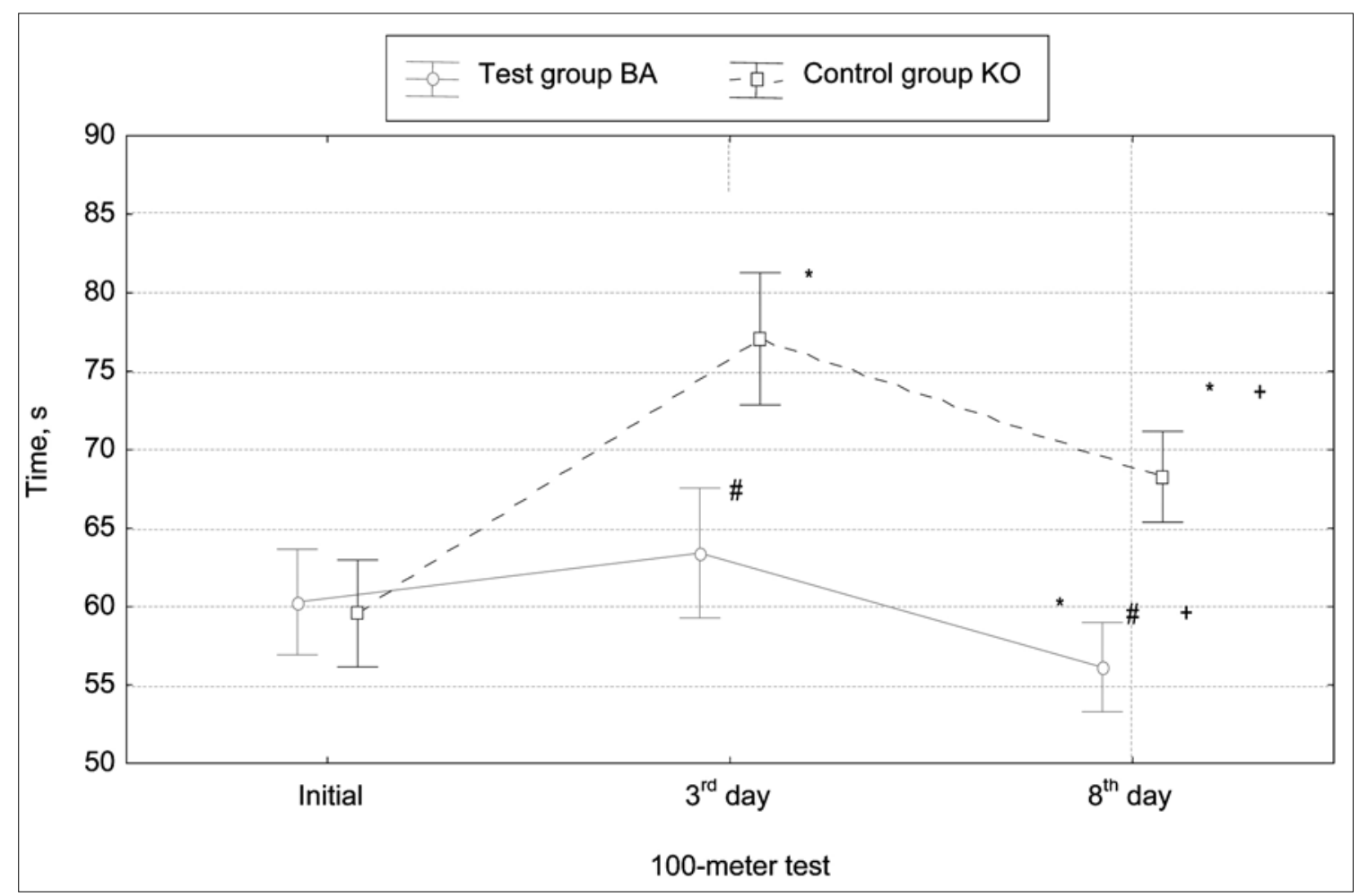

Figure 2. Comparison of effort tolerance level in the 6-minute walk test in the corridor (Series 1) and on the treadmill (Series 2)

Note. * - statistically significant difference $(p \leq 0.05)$ between consecutive tests; \#- statistically significant difference $(p \leq 0.05)$ between groups in a particular test; + - statistically significant difference $(p \leq 0.05)$ in relation to initial test.

\section{DISCUSSION}

Professional publications have so far not discussed the influence of Kinesio Taping on the effects of physiotherapy in patients after laparoscopic cholecystectomy (CHL).

The possibility of using KT in surgery have been reported in professional literature. The usefulness of KT application for stabilizing post-operative wounds has been proved $[8,9,10]$. However the effects of complex physiotherapy involving KT applications in general surgery, including laparoscopic cholecystectomy, have not been discussed.

It is assumed that cholecystectomy might lead to a decrease in lung capacity and the surgery might affect lung ventilation activity as seriously as surgeries within thoracic cavity. This might be caused by a significant postoperative intestinal distention, lasting longer than after other surgeries, deriving from reduced post-anesthetic peristalsis or frequently surgical intervention within the intestines. Such a situation leads to higher positioning of the diaphragm which reduces its movement amplitude. The surgery causes a decrease in forced ventilation capacity and expiratory volume. It might lead to a decrease in partial pressure of oxygen $\left(\mathrm{PaO}_{2}\right)$, secretion of discharge in bronchi and limitations tolerance $[1,11,12]$.

Initiated early and controlled physical training prevents disorders and complications within cardio- respiratory system and a rapid loss of physical efficiency $[2,11]$.

The analysis carried out in this research showed that the time achieved in the 100-meter walk test by patients from the group where KT applications were used was significantly shorter than the time achieved by patients in the control group. A detailed post hoc analysis showed a significantly longer time achieved in the tests conducted on the third and eighth day in patients from the group where KT applications were not used. This proves the increase in effort tolerance being the effect of the physiotherapy process complemented by KT applications. Similar results were achieved in research carried out with patients after surgeries within abdominal cavity [13].

KT creates the possibility of providing effective support for physiotherapy and through stabilization of post-operative wound and reducing functional disorders occurring after laparoscopic cholecystectomy may indirectly enhance the effects of physiotherapy within the short time of hospital treatment. KT is one of the methods of physiotherapy allowing to achieve the results expected after laparoscopic cholecystectomy in a short time period. It might reduce hospitalization time for these patients. 


\title{
CONCLUSIONS
}

1. The improvement in effort tolerance achieved in the research indicates the efficiency of Kinesio Taping as a method supporting physiotherapy in patients after laparoscopic cholecystectomy.
2. Kinesio Taping effectively complements physiotherapy and by means of stabilization of post-operative wound reduces the occurrence of functional disorders resulting from laparoscopic cholecystectomy consequently leading to shortening hospitalization time.

\section{REFERENCES}

1. Wozniewski, M., Kolodziej, J. (2006). Rehabilitacja w chirurgii. Warszawa: Wydawnictwo Lekarskie PZWL.

2. Wozniewski, M., Marocka-Maczka, K. (1990). Usprawnianie chorych po operacjach w obrebie jamy brzusznej. Advances in Rehabilitation, 4 (1), 71-77.

3. Kase, K., Wallis, J., Kase, J. (2003). Application Therapeutic of the Kinesio Taping Method. Tokyo: Kinesio Taping Association.

4. Lohrer, H., Alt, W., Gollhofer, A. (1999). Neuromuscular properties and functional aspects of taped ankles. American Journal of Sports Medicine, 27, 69-75.

5. Breitenbach, S. (2007). Schwangerschaft und Kinesio-Tape. Physikalische Therapie, 5, 287-289.

6. Tomoyoshi, N. (2006). Kinesio Taping Approach for Lumbago of Pregnant Women: 21 Kinesio Taping Symposium (pp. 15-20). Tokyo, Japan.

7. American Thoracic Society. Guidelines for the six-minute walk test. (2002). American Journal of Respiratory and Critical Care Medicine, 166, 111-117.
8. Szczegielniak, J., Krajczy, M., Bogacz, K., Luniewski, J., Sliwinski, Z. (2007). Kinesiotaping after thoracosurgeries. Polish Journal of Physiotherapy, 7 (3), 344-350.

9. Szczegielniak, J., Krajczy, M., Bogacz, K., Luniewski, J., Sliwinski, Z. (2007). Kinesiotaping in physiotherapy after abdominal surgery. Polish Journal of Physiotherapy, 7 (3), 299-307.

10. Szczegielniak, J., Luniewski, J., Bogacz, K., Krajczy, M., Sliwinski, Z. (2007). The possibilities of using Kinesio Taping in patients after cardiac surgery. Polish Journal of Physiotherapy, 7 (4), 465-470.

11. Adamczyk, M. (1999). Kinezyterapia w działaniach profilaktycznych powikłań pooperacyjnych w chirurgii ogólnej. Nowa klinika, 6 (1), 23-24.

12. Wozniewski, M. (2002). Rehabilitacja w specjalnościach zabiegowych. In Kwolek A. (Red.), Rehabilitacja medyczna. Vol II. Wrocław: Wydawnictwo Medyczne Urban \& Urban.

13. Krajczy, M., Szczegielniak, J., Sliwinski, Z., Kaminski, K. (2008). The effectiveness of Kinesio Taping applications in physiotherapy of post-cholecystectomy patients: Preliminary report. Polish Journal of Physiotherapy, 8 (3), 279-289.

\section{MINKŠTOJO ITVARO KLIJAVIMO POVEIKIS FIZINIO KRŪVIO TOLERANCIJAI PO LAPAROSKOPINĖS CHOLECISTEKTOMIJOS}

\author{
Marcin Krajczy ${ }^{1,2}$, Jan Szczegielniak ${ }^{1}$, Katarzyna Bogacz'1, Jacek Luniewski ${ }^{1}$ \\ Opolès technologijos universitetas ${ }^{1}$ \\ Nysos viešoji ligoniné ${ }^{2}$
}

\section{SANTRAUKA}

Atlikus laparoskopinę cholecistektomiją, kineziterapijos metu ligoniai jaučia skausmą, ir tai mažina jų aktyvumą, neigiamai veikia kvėpavimo raumenų funkciją ir apsitarnavimo kokybę.

Tyrimo tikslas - nustatyti minkštojo įtvaro klijavimo (K-active tape) poveiki fizinio krūvio tolerancijai po laparoskopinės cholecistektomijos. Tyrimo uždavinys buvo palyginti tiriamosios ir kontrolinės grupès $100 \mathrm{~m}$ èjimo testo rezultatus prieš operaciją, prieš kineziterapiją ir po jos.

Buvo tiriami 63 ligoniai po laparoskopinès cholecistektomijos, atliktos Nysos ligoninès chirurgijos skyriuje. Tiriamąją (BA) ir kontrolinę $(\mathrm{KO})$ grupes sudare atsitiktinai atrinkti savanoriai, atitinkantys atrankos kriterijus. BA grupę sudarè 32 ligoniai (26 moterys ir 6 vyrai), KO - 31 ligonis (22 moterys ir 9 vyrai). Abiems grupėms taikyta kineziterapija, o BA grupei papildomai klijuotas minkštasis ¡̇tvaras. Tyrimo rezultatai apdoroti šiais matematinès statistikos metodais: taikytas U Mann-Whitney testas. Pasirinktas statistinio reikšmingumo lygmuo $p<0,05$.

Vertinant vidutini $100 \mathrm{~m}$ ejjimo laiką prieš laparoskopinę cholecistektomiją, statistiškai reikšmingo skirtumo tarp tiriamųjų grupių rezultatų nepastebèta. Vèlesnių $100 \mathrm{~m}$ èjimo testų metu BA grupės tiriamųjų èjimo laikas buvo statistiškai trumpesnis nei KO.

Išvada: fizinio krūvio tolerancijos pagerèjimas pagrindžia minkštojo įtvaro klijavimo, kaip kineziterapijos metodo, veiksmingumą po laparoskopinès cholecistektomijos.

Raktažodžiai: minkštojo įtvaro klijavimas, laparoskopinė cholecistektomija, kineziterapija. 